\title{
PENGARUH EKUITAS MERK DAN LINGKUNGAN SOSIAL TERHADAP NIAT BELI KONSUMEN PADA PRODUK GIORDANO
}

\author{
Putu Mona Prabawa Putra ${ }^{1}$ \\ Kastawan Mandala ${ }^{2}$ \\ ${ }^{1,2}$ Fakultas Ekonomi dan Bisnis Universitas Udayana (Unud), Bali, Indonesia \\ email: monaprabawa@yahoo.com
}

\begin{abstract}
ABSTRAK
Makalah penelitian bertujuan mengguji pengaruh ekuitas merk dan lingkungan sosial terhadap niat beli konsumen pada produk Giordano di Kota Denpasar. Karya ilmiah ini dilakukan di Kota Denpasar dengan teknik analisis data regresi linear berganda. Ukuran sampel yang didapat sebanyak 120 responden dengan menggunakan metode purposive sampling. Hasil analisis dapat dikemukakan bahwa ekuitas merek secara langsung berpengaruh positif terhadap niat beli konsumen pada produk pakaian Giordano di Kota Denpasar. lingkungan sosial secara langsung berpengaruh positif terhadap niat beli konsumen pada produk pakaian Giordano di Kota Denpasar. Direkomendasikan saran untuk Giordano harus dengan jelas menggambarkan produk merek Giordano dimata konsumen sehingga konsumen sanggup dalam mengenali produk merek Giordano dan tertarik untuk melakukan pembelian. Memberikan informasi mengenai produk Giordano lebih baik dan detail lagi kepada konsumen sehingga dapat dipromosikan kepada keluarganya, tetangganya dalam menambah referensi di dalam melalukan pembelian.
\end{abstract}

Kata kunci : lingkungan sosial, ekuitas merek, dan niat beli

\begin{abstract}
The research paper aims to leverage the influence of brand equity and social environment on consumer buying intentions on Giordano products in Denpasar City. This scientific work is done in Denpasar City with multiple linear regression analysis technique. The sample size is 120 respondents by using purposive sampling method. The results of the analysis can be stated that brand equity directly affects positively to consumer purchase intentions on clothing products Giordano in the city of Denpasar. The social environment directly positively affects consumers' purchase intentions on Giordano clothing products in Denpasar City. Recommended suggestions for Giordano should clearly illustrate Giordano brand products in the eyes of consumers so that consumers are able to recognize Giordano brand products and are interested in making purchases. Provides information about Giordano's products better and more detail to the consumer so that it can be promoted to his family, his neighbors in adding references in making a purchase.
\end{abstract}

Keywords: social environment, brand equity, and purchasing intentions 


\section{PENDAHULUAN}

Perubahan perilaku niat beli konsumen di masyarakat menyebabkan terjadinya pergeseran sikap konsumen dalam mengartikan suatu produk, dimana yang awalnya menganggap bahwa untuk memiliki suatu produk karena manfaatnya, namun sekarang bergeser bahwa memiliki produk karena nilai produk itu sendiri yang dapat memenuhi keinginannya dan meningkatkan prestise atau gengsi, dalam artian nilai pelanggan sangat penting bagi konsumen. Budaya niat beli saat ini dirasakan semakin meningkat, terutama di bidang fashion yang dilihat dari semakin banyaknya pusat perbelanjaan di Indonesia dan Kota-kota besar seperti Provinsi Bali yang tidak kalah hebat dengan pusat perbelanjaan kelas Dunia. Melihat peluang ini banyak merk terkenal dan mewah kelas Dunia yang membuka toko penjualan di Indonesia untuk memanjakan sifat konsumerisme masyarakat Indonesia, sebut saja merk terkenal seperti Versace, Giordano, Louis Vuitton, Jimmy Choo, Prada, Bally, Christian Loubuttin, dll (Merdeka.com, 2016). Mal-mal atau pusat perbelanjaan tersebut selalu saja dipenuhi oleh pengunjung, sebagian pengamat Ekonomi mengindikasikan potensi daya beli masyarakat yang besar terjadi di Indonesia (Julina dan Desrir, 2014).

Kebutuhan dengan barang berkualitas dengan gaya hidup sebagian besar masyarakat di Kota Denpasar sebagai suatu keharusan yang dialami oleh setiap konsumen, Fenomena ini sudah terjadi dari dahulu hingga sampai saat ini. Keadaan ini yang membuat setiap produsen produk mewah dan berkelas ikut meramaikan pasar di Bali khususnya Kota Denpasar bertujuan untuk mampu meningkatkan 
pendapatan melalui penjualan produk-produk yang mereka ditawarkan. Produk Giordano yang menawarkan produk dengan rancangan bergaya casual serta menarik dengan gaya modern selalu mengikuti perkembangan mode anak muda dengan desain untuk para kalangan muda, remaja dan dewasa. Produk Giordano mudah ditemukan di hampir seluruh pusat perbelanjaan serta plasa di Indonesia termasuk Bali. Produk fashion Giordano seperti kaos polo, kemeja, celana panjang, celana pendek pria dan wanita, sweater, baju anak, pakaian wanita, serta aneka produk fashion lainnya. Produk Giordano berusaha memberikan perubahan dengan inovasi mode yang menarik serta up to date dengan tampilan produk yang fashionable untuk berpenampilan dengan gaya modis yang memberikan kesan lebih keren dimata orang lain, sehingga banyak kalangan menyukai serta membeli produk Giordano dikarenakan mengikuti trend mode terbaru yang menjadi panutan masyarakat (Merdeka.com, 2016).

Konsumen saat ini memiliki alternatif pilihan yang lebih banyak dengan kemajuan teknologi serta meluasnya jaringan perusahaan fashion, baik itu produk dalam negeri ataupun dari luar negeri (Parisa, 2014). Tren yang berkembang di negara lain atau negara berkembang akan dengan mudah diakses oleh masyarakat atau konsumen dari belahan dunia lain sehingga berpotensi memunculkan permintaan akan suatu produk yang lebih banyak dari masa sebelumnya. Hal ini dipermudah lagi dengan adanya perjanjian perdagangan antar negara yang membuat konsumen semakin mudah memperoleh produk asing karena dipasarkan juga di negaranya 
sendiri (Rahmawati et al., 2007). Tren membanjirnya produk-produk asing di pasar negara lain juga terjadi di Indonesia, bahkan sebagian konsumen Indonesia mempersepsikan bahwa produk-produk asing sering memiliki berbagai kelebihan dibanding produk dalam negeri. Walaupun secara kualitas kadang-kala produk dalam negeri mampu bersaing dengan produk impor, namun kesenangan mengikuti tren terbaru membuat konsumen tetap memburu produk impor (Sreejesh, 2015). Penggunaan produk-produk impor ini juga dianggap dapat meningkatkan harga diri sehingga merasa lebih diakui oleh lingkungan masyarakat (Sudomo, 2014).

Ayu dan Kerti, 2014 menyatakan bagi konsumen yang orientasi dirinya bertumpu pada prinsip hidup, yaitu di dalam mengambil keputusan membeli selalu berdasarkan keyakinannya, sehingga keputusannya untuk membeli bukan hanya karena ikut-ikutan atau sekedar untuk mengejar gengsi, dapat dikatakan tipe ini lebih rasional. Sedangkan yang bertumpu pada emosional, keputusannya dalam membeli di dominasi oleh konsumen lain. Produk-produk branded (bermerek) cenderung menjadi pilihannya dan tidak berpikir lebih lanjut akan manfaatnnya (Kambiz and Mohammad, 2012).

Kevin (2014) menyebutkan bahwa kekuatan merek terletak pada kemampuannya memikat konsumen untuk membeli produk yang diinginkannya. Merek penting bagi perusahaan untuk menunjukkan nilai produk yang ditawarkan ke pasar, namun merek tidak berarti jika tidak memiliki ekuitas yang kuat bagi pasar (Johan, 2010). Kotler dan Keller (2009:263), ekuitas merek adalah nilai tambah yang 
diberikan pada produk dan jasa. Ekuitas merek dapat tercermin dalam cara konsumen berpikir, merasa, dan bertindak dalam hubungannya dengan merek, dan juga harga, pangsa pasar, dan profitabilitas yang diberikan merek bagi perusahaan. Bagi perusahaan yang sadar akan makna penting dan strategisnya merek, ekuitas merek menjadi hal yang selalu diperhatikan dan pengukurannya dilakukan secara teratur, karena ekuitas merek dapat dianggap sebagai tambahan arus kas yang diperoleh melalui pengaitan nama merek dengan produk/jasa yang mendasarinnya (Eko dan Budi, 2013). Ekuitas merek yang kuat dapat menyebabkan minat beli konsumen/calon konsumen yang tinggi (Andrie dan Harold, 2013).

Terlepas dari ekuitas merk, faktor lingkungan sosial yang baik pada umumnya akan lebih memotivasi konsumen untuk membeli produk sehingga memiliki keyakinan bahwa produk tersebut berkualitas yang baik serta dapat dipercaya (Sudomo, 2013). Lingkungan sosial adalah lingkungan sekitar konsumen yang terdiri dari kelompok rujukan dan keluarga (Jamaliah et al., 2013). Rekan kerja, teman dan tetangga dapat dikategorikan menjadi kelompok rujukan yang secara langsung maupun tidak langsung dapat mempengaruhi niat beli konsumen. Keluarga merupakan organisasi pembelian konsumen yang paling penting dalam masyarakat dan para anggota keluarga menjadi kelompok acuan primer yang paling berpengaruh (Joshi, 2012). Keluarga terdiri atas orang tua dan anak-anak yang memiliki pengaruh dalam pengambilan keputusan membeli sejumlah besar produk dan jasa yang ditawarkan. Zohreh and Arman (2013) menyatakan bahwa pembelian produk fashion 
didorong oleh referensi dari keluarga dan teman. Pembelian juga didorong dengan adanya fakta bahwa produk fashion tersebut semakin memiliki kualitas yang baik. Kuang et al. (2011) dalam penelitiannya menyatakan peran lingkungan sosial memiliki korelasi positif terhadap niat beli konsumen terhadap produk merek mewah.

Di dalam pemilihan suatu merek, konsumen akan memilih suatu merek tertentu yang mencerminkan serta memperkuat identitas diri mereka agar diterima di komunitas tertentu atau untuk meningkatkan harga diri orang tersebut secara individu yang disebut dengan ekuitas merk. Menurut David dalam Kotler dan Keller (2007), ekuitas merek sebagai perangkat aset merek yang berkaitan dengan nama dan simbolnya, yang menambah atau mengurangi nilai yang diberikan oleh sebuah barang atau jasa kepada perusahaan atau para pelanggan perusahaan. Ekuitas merek (brand equity) adalah seperangkat asosiasi dan perilaku yang dimiliki oleh pelanggan merek, serta perusahaan yang memungkinkan suatu merek mendapatkan kekuatan, daya tahan, dan keunggulan yang dapat membedakan dengan merek pesaing (Andrie dan Harold, 2013). Kuenzel dan Halliday (2008:293) menyatakan bahwa orang biasanya melampui identitas diri mereka untuk melakukan pembelian terhadap merk. Dalam konteks pemasaran, pelanggan melakukan pembelian melalui identifikasi serta mengasosiasikan dirinya dengan merek sehingga mencerminkan, memperkuat identitas diri di masyarakat. Merk produk Giordano misalnya, orang memilih merk Giordano dikarenakan memiliki prestise serta kualitas yang tinggi terlihat dari segi 
bahan, keawetan warna sehingga masyarakat merasakan suatu peningkatan harga diri apabila menggunakan produk Giordano.

Giordano dikenal sebagai perusahaan pembuat pakaian kasual diperuntukan bagi pria, wanita, serta anak-anak. Hang Ten, Esprit, Guess, U2 dan masih banyak lagi lainnya sebagai pesaing yang ikut berkompetisi dalam pasar penjualan, sehingga memicu persaingan yang sangat ketat dimana harga yang ditawarkan pun semakin lama semakin turun. Dengan banyaknya pesaing dalam industri yang sama menandakan adanya persaingan yang tajam. Adanya persaingan yang ketat di sektor industri telah mendorong manajemen perusahaan untuk mengelola produk dan jasa mereka agar mengena di hati konsumen. Giordano harus berusaha meminimalkan resiko secara finansial/value for money, emosional, sosial, dan kualitas yang dirasakan konsumen. Strategi positioning terhadap ekuitas merek tidaklah cukup dalam melakukan pembelian dan mengkonsumsi sebuah produk pakaian sehingga perlu adanya strategi dalam pengenalan lingkungan sekitar konsumen.

Fenomena masalah ini secara langsung member gambaran kencenderungan konsumen untuk membeli produk fashion berdasarkan pemakaian dikarenakan simbol merk yang dikenakan. Konsumen menggunakan status produk sebagai simbol untuk mengkomunikasikan kepada kelompok referensi yang responnya sangat penting bagi pemakai produk (Yungki, 2010). Masyarakat Indonesia seperti Bali, misalkan masyarakat diperkotaan ataupun pedesaan dapat dikategorikan kedalam masyarakat yang sangat konsumtif dan memiliki harga diri yang berlebihan sehingga memberikan 
peranan sangat besar dalam melakukan niat beli, apalagi masyarakat di perkotaan yang juga memiliki harga diri lebih tinggi, walaupun semakin mahal harga produk yang dijual semakin banyak yang berniat untuk membeli. Tidak heran Indonesia seperti Bali menjadi tujuan utama ekspor produk-produk dari luar Negeri, dikarenakan masyarakat Indonesia terbilang gila pada produk luar Negeri berdasarkan harga diri mereka.

Melalui pemaparan masalah yang telah dijabarkan, didukung dengan karya ilmiah dan teori tujuan dari karya ilmiah ini yang hendak dicapai 1) Bagaimana pengaruh ekuitas merk terhadap niat beli konsumen pada pakaian Giordano di Kota Denpasar, 2) Bagaimana pengaruh lingkungan sosial terhadap niat beli konsumen pada pakaian Giordano di Kota Denpasar.

Merk

Asosiasi Pemasar Amerika (Kotler dan Amstrong, 2012) mendefinisikan merek sebagai nama, istilah, tanda, simbol, atau rancangan, atau kombinasi dari semuanya, yang dimaksudkan untuk mengidentifikasikan barang atau jasa atau kelompok penjualan dan untuk mendiferensiasikannya dari barang dan jasa pesaing. Menurut Undang-Undang Merek No. 15 Tahun 2001 pasal 1 ayat 1 merek merupakan tanda yang berupa gambar, nama, kata, huruf-huruf, angka-angka, susunan warna, atau kombinasi dari unsur-unsur tersebut yang memiliki daya pembeda dan digunakan dalam kegiatan perdagangan barang dan jasa. 
Ekuitas Merk

Menurut Aaker (1997) ekuitas merek adalah serangkaian aset dan kewajiban yang terkait dengan sebuah merek, nama, simbolnya, yang menambah dan mengurangi nilai yang diberikan sebuah produk dan jasa kepada perusahaan atau pelanggan perusahaan tersebut. Menurut Kotler (2007) ekuitas merek adalah nilai tambah yang diberikan pada produk dan jasa. Nilai ini bisa dicerminkan dalam cara konsumen berfikir, merasa, dan bertindak terhadap merek, harga, pangsa pasar, dan profitabilitas yang dimiliki perusahaan.

\section{Lingkungan Sosial}

Menurut Purimahua (2005) dalam Yungki (2010) lingkungan sosial adalah sekelompok orang yang mampu mempengaruhi perilaku individu dalam melakukan suatu tindakan berdasarkan kebiasaan. Nick (2013) Faktor sosial terdiri dari kelompok referensi, keluarga, peran dan status sosial. Kotler (2007:203) menyatakan lingkungan sosial yang mempengaruhi perilaku konsumen dalam melakukan proses pembelian terdiri atas: kelompok acuan merupakan seseorang yang terdiri dari semua kelompok yang memiliki pengaruh langsung (tatap muka) terhadap sikap dan perilaku seseorang. Keluarga merupakan organisasi pembeli yang paling penting dalam masyarakat, yang terdiri atas ayah, ibu, dan anak-anaknya. Setiap keputusan dalam proses pembelian selalu dipengaruhi oleh faktor keluarga dan bersifat 
signifikan, dan peran meliputi kegiatan yang diharapkan akan dilakukan oleh seseorang, dimana setiap peran yang dilakukan memiliki status (Tanya, 2014).

Niat Beli

Niat beli dapat didefinisikan sebagai niat seseorang untuk membeli merek tertentu yang telah mereka pilih untuk diri mereka sendiri setelah mengevaluasi. Kita dapat mengukur variable niat beli misalnya mempertimbangkan merek untuk pembelian dan mengharapkan untuk membeli produk tersebut dimasa yang akan datang (Kotler dan Keller, 2007: 189). Untuk melakukan niat beli merek tertentu memerlukan penilaian dari semua merek yang tersedia di pasar (Sudomo, 2014). Hal ini menunjukkan pendekatan terhadap suatu merek tertentu memiliki efek yang besar pada niat beli (Yungki, 2010). Sikap merek memiliki hubungan positif dengan niat beli, hal ini juga menunjukkan bahwa niat seseorang ditentukan oleh sikap terhadap merek yang sama dan lainnya. Niat beli menunjukkan bahwa konsumen mengejar pengalaman, keinginan eksternal lingkungan mereka untuk mengumpulkan informasi tentang produk atau jasa (Schiffman dan Kanuk 2007:128).

\section{Perilaku Konsumen}

Suprapti (2010:68) persepsi merupakan sebuah proses yang harus dilalui oleh konsumen untuk memilih, mengorganisasi, menginterpretasi stimuli ke dalam sebuah gambaran yang bersifat koheren. Menurut Mangkunegara (2011:21) "Perilaku konsumen didefinisikan sebagai tindakan individu yang secara langsung terlibat dalam usaha memperoleh dan menggunakan barang-barang serta jasa ekonomis 
termasuk proses pengambilan keputusan yang mendahului dan menentukan tindakantindakan tersebut". Perilaku konsumen (consumer behavior) adalah proses yang terjadi pada konsumen ketika memutuskan untuk membeli, apa yang dibeli, dimana, kapan, dan bagaimana membelinya. Sehingga, dapat disimpulkan bahwasanya perilaku konsumen merupakan suatu proses yang terus-menerus (berkesinambungan).

\section{Perilaku Niat Beli}

Pavlou (2003) dalam niat untuk bertransaksi, dapat didefinisikan sebagai niat konsumen untuk terlibat dalam berbagai hubungan pertukaran online dengan penjual pada suatu web, seperti berbagi informasi bisnis, menjaga hubungan bisnis, dan melakukan transaksi bisnis. Perilaku niat didefinisikan Mowen and Minor (2007) sebagai keinginan konsumen untuk berperilaku menurut cara tertentu dalam rangka memiliki, membuang, dan menggunakan produk atau jasa. Jadi konsumen dapat membentuk keinginan untuk mencari informasi, memberitahukan orang lain tentang pengalamannya dengan sebuah produk, membeli sebuah produk atau jasa tertentu, atau membuang produk dengan cara tertentu.

Jenis Perilaku Pembelian

Pengambilan keputusan konsumen akan berbeda-beda, tergantung pada jenis keputusan pembelian. Pembelian yang rumit dan mahal akan melibatkan lebih banyak pertimbangan yang diperlukan oleh pembelian. Menurut Assael (Kotler, 2007:221), terdapat empat jenis perilaku pembelian konsumen berdasarkan 
tingkat keterlibatan pembeli dan tingkat diferensiasi mereka, yaitu: Perilaku pembelian yang rumit, Perilaku pembelian pengurang ketidaknyamanan/ Disonasi, Perilaku pembelian karena kebiasaan, Perilaku pembelian yang mencari variasi

\section{Rumusan Hipotesis}

Kotler and Keller (2007:263), ekuitas merek adalah nilai tambah yang diberikan pada produk dan jasa. Ekuitas merek dapat tercermin dalam cara konsumen berpikir, merasa, dan bertindak dalam hubungannya dengan merek, dan juga harga yang dapat meningkatkan niat beli konsumen. Andrie et al. (2013) menyebutkan bahwa kekuatan merek terletak pada kemampuannya memikat konsumen untuk membeli produk yang diinginkannya. Merek penting bagi perusahaan untuk menunjukkan nilai produk yang ditawarkan ke pasar, namun merek tidak berarti jika tidak memiliki ekuitas yang kuat bagi pasar (Eko dan Budi, 2013).

Sudomo (2014) menemukan ekuitas merk yang diterapkan mampu memberikan dampak positif dan signifikan dalam menciptakan niat beli pelanggan. Ini pun diungkapkan oleh Yungki (2010) penerapan ekuitas merk mampu menciptakan dampak positif signifikan terhadap niat beli konsumen. Eko dan Budi (2013) menyatakan ekuitas merk memberikan pengaruh positif signifikan terhadap niat beli konsumen. Berdasarkan pemahaman tersebut dapat dirumuskan hipotesis pertama sebagai berikut.

$\mathrm{H}_{1}$ : ekuitas merk mempengaruhi niat beli konsumen secara positif. 
Kotler and Keller (2007:119) lingkungan sosial seseorang akan memperlihatkan citra dirinya di masyarakat untuk dapat menunjukkan kepada orang lain kemampuan ekonomi yang dimilikinya, sehingga lingkungan sosial seseorang akan mempengaruhi niat beli seseorang pada suatu produk. Lingkungan sosial dalam ruang lingkup konsumen memberikan dampak positif signifikan terhadap niat beli konsumen pada produk (Ling, 2010). Zohreh and Arman (2013) menyatakan bahwa peran lingkungan sosial mampu berdampak positif signifikan terhadap niat beli konsumen. menyatakan bahwa lingkungan sosial berpengaruh positif terhadap niat beli konsumen (Sutomo, 2013). Berdasarkan hasil penelitian tersebut, diajukan hipotesis ke tiga sebagai berikut.

$\mathrm{H}_{2}$ : lingkungan sosial mempengaruhi niat beli konsumen secara positif.

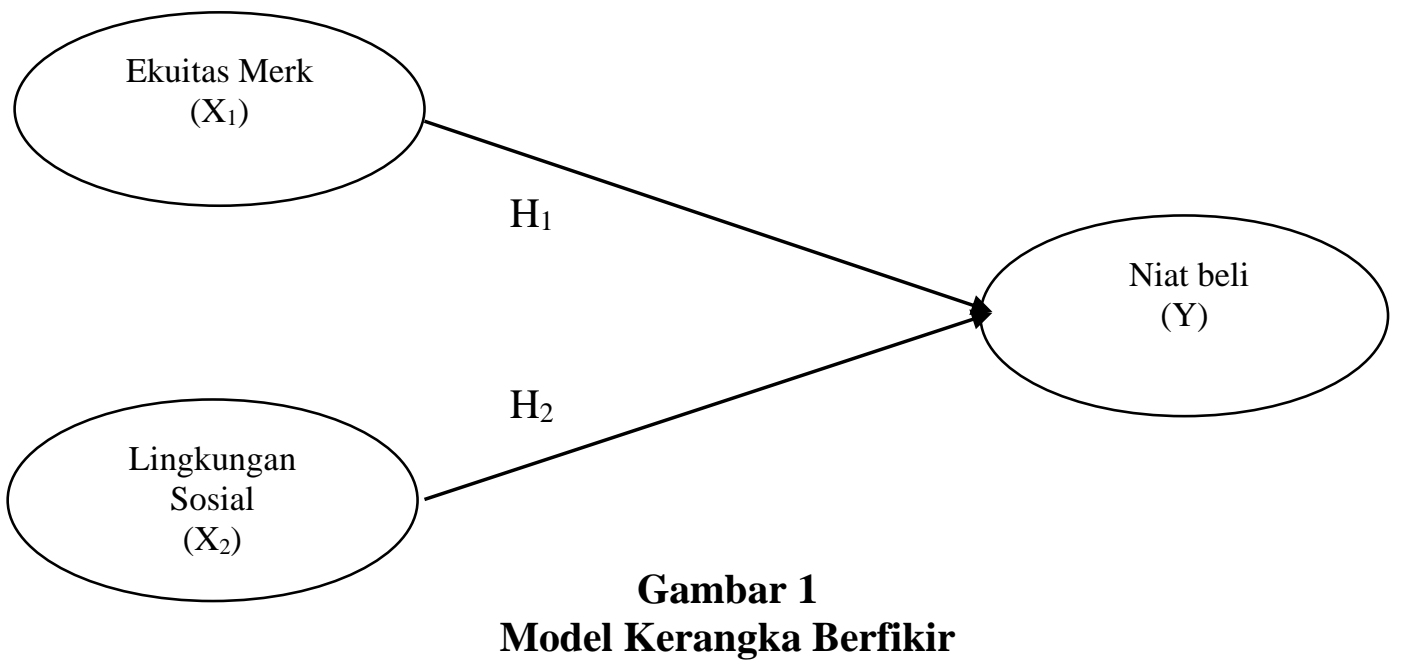

METODE PENELITIAN

Karya ilmiah ini menggunakan metode asosiatif yang bertujuan untuk mengetahui pengaruh ataupun juga hubungan antara dua variabel atau lebih 
(Sugiyono, 2010). Lokasi penelitian dipilih Kota Denpasar sebagai pusat kota dengan pertumbuhan sektor ekonomi masyarakat sangat cepat, jumlah penduduk yang padat dan populasi yang cukup tinggi. Selain itu secara teknis, Kota Denpasar memenuhi kategori yang dinilai efektif dan efisien dalam menyelenggarakan penelitian yang relevan, dimana mayoritas masyarakatnya merupakan masyarakat modern yang saat ini kebanyakan ingin memenuhi kebutuhannya dengan niat beli yang tinggi untuk mengikuti trend gaya hidup mewah.

Obyek penelitian adalah suatu hal atau apa saja yang menjadi perhatian dan apa saja yang diteliti (kamus bahasa Indonesia, 2008). Sebagai obyek dalam penelitian adalah niat beli konsumen pada produk Giordano di Kota denpasar.

Subyek penelitian ini adalah konsumen yang memiliki niat beli pada produk Giordano di Kota Denpasar. Variabel bebas adalah ekuitas merk $\left(\mathrm{X}_{1}\right)$ dan lingkugan sosial $\left(\mathrm{X}_{2}\right)$, variabel terikat adalah niat beli konsumen $(\mathrm{Y})$.

Jenis data Data Kualitatif yang dipergunakan seperti teori-teori yang mendukung penelitian. Data Kuantitatif yang dipergunakan seperti adalah data tanggapan responden terhadap kuisioner yang diberikan, jumlah populasi dan sampel responden pada konsumen Giordano di Kota Denpasar. Sumber data untuk mendukung makalah studi ini seperti sumber data primer dan sekunder. Data primer melalui data yang dikumpulkan dari tangan pertama, catatan dan dipergunakan langsung dari pendapat konsumen mengenai produk Giordano, diamati dan dicatat untuk pertama kalinya oleh peneliti, data ini didapatkan dengan observasi dan 
pemberian kuesioner. Data sekunder diperoleh dari tempat objek penelitan dalam bentuk jadi untuk pendukung karya ilmiah ini mengenai produk Giordano dan sejarah Kota Denpasar.

Jumlah sampel dalam hal ini konsumen yang memiliki niat beli pada produk Giordano di Kota Denpasar sebanyak 120 orang di klasifikasikan berdasarkan metode teknik purposive sampling (Sugiyono, 2010:17). Data yang dikumpulkan dalam penelitian ini menggunakan metode wawancara, dengan melakukan tanya jawab langsung antara peneliti dengan responden yang terkait untuk mendapatkan informasi yang dibutuhkan. Kuisioner melalui pertanyaan terstruktur yang telah dipersiapkan sebelumnya dan diberikan kepada responden yang telah dipilih dan dipergunakan untuk memperoleh data konsumen atau responden. Studi Pustaka adalah metode pengumpulan data sekunder yang bersumber pada buku, literatur, jurnal-jurnal, referensi yang terkait dengan penelitian yang sedang dilakukan.

Pengujian Instrumen Penelitian

Sebuah instrumen dikatakan valid jika mampu mengukur apa yang seharusnya diukur, dan dapat mengungkap data dari variabel yang diteliti secara tepat. Tinggi rendahnya validitas instrumen menunjukkan sejauh mana data yang terkumpul tidak meyimpang dari gambaran tentang variabel yang dimaksud, yang dianggap memenuhi syarat adalah jika $r \geq 0,3$ dengan signifikansi $<0,05$ ".

Umar (2007:194) bahwa reliabilitas adalah suatu angka indeks yang menunjukan kosistensi suatu alat ukur dalam mengukur gejala yang sama. Uji 
reliabilitas mampu menunjukan sejauh mana instrument dapat dipercaya dan diharapkan. Nilai suatu instrumen dikatakan reliabel bila nilai Alpha Cronbach $\geq 0,6$.

\section{Uji Asumsi Klasik}

Karena dalam penelitian ini menggunakan statistik parametrik dengan model regresi berganda, maka sebelumnya perlu dilakukan uji asumsi klasik yang meliputi: Uji Normalitas, bertujuan untuk menguji apakah suatu data berdistribusi normal atau tidak. Uji Multikoliniaritas, uji ini bertujuan untuk menguji apakah dalam model regresi ditemukan adanya kolerasi antara variabel-variabel bebas. Jika terjadi kolerasi maka dinamakan terjadi problem multikolonieritas. Model regresi yang baik seharusnya tidak terjadi kolerasi antara variabel-variabel bebas (Umar, 2007:198). Uji heteroskedastisitas, menurut Ghozali (2006:105) uji heteroskedastisitas tujuan dari asumsi ini adalah menguji apakah dalam model regresi terjadi ketidaksamaan varians dari residual satu ke pengamatan yang lain tetap maka disebut homokedasitas jika berbeda disebut heteroskedastisitas.

Data diuji menggunakan analisis regresi linier berganda, untuk mengetahui ketergantungan suatu variabel terikat dengan satu atau lebih variabel bebas. Adapun bentuk umum dari persamaan regresi linier berganda menurut (Suyana, 2008:93) sebagai berikut.

$$
\begin{aligned}
& \mathrm{Y}=\alpha+\beta_{1} X_{1}+\beta_{2} X_{2}+\mu i \\
& \text { Dimana : } \\
& \mathrm{Y} \quad=\text { Niat Beli } \\
& \mathrm{X}_{1}=\text { Ekuitas Merk } \\
& \mathrm{X}_{2} \quad=\text { Lingkungan Sosial } \\
& \alpha \quad=\text { Konstanta }
\end{aligned}
$$




$$
\begin{aligned}
\beta_{1-} \beta_{3}= & \text { Koefisien regresi dari } \mathrm{X}_{1}-\mathrm{X}_{3} \\
\mu i= & \text { Variabel pengganggu (residual error) yang mewakili faktor lain } \\
& \text { berpengaruh terhadap } \mathrm{Y} \text { namun tidak dimasukkan dalam model. }
\end{aligned}
$$

\section{Uji F-test dan Uji Hipotesis (T-test)}

Uji F-test untuk menguji model regresi pengaruh variabel bebas ekuitas merk $\left(\mathrm{X}_{1}\right)$ dan lingkungan sosial $\left(\mathrm{X}_{2}\right)$ secara serempak terhadap variabel terikat niat beli konsumen (Y). Uji t-test bertujuan untuk menguji signifikansi pengaruh variabel bebas ekuitas merk $\left(\mathrm{X}_{1}\right)$ dan lingkungan sosial $\left(\mathrm{X}_{2}\right)$ secara parsial terhadap variabel terikat niat beli konsumen (Y).

\section{HASIL DAN PEMBAHASAN}

Hasil uji validitas masih-masing indikator variabel memiliki nilai person correlation lebih besar dari 0,30 , maka ini berarti indikator/pertanyaan yang digunakan layak digunakan untuk mengukur apa yang seharusnya diukur, dan dapat mengungkap data dari variabel yang diteliti secara tepat yang disajikan pada Tabel 1.

\begin{tabular}{|c|c|c|c|c|}
\hline No & Variabel & Indikator & Korelasi & Keterangan \\
\hline \multirow{4}{*}{1} & \multirow{4}{*}{ Ekuitas Merek $\left(\mathrm{X}_{1}\right)$} & $\mathrm{X} 1.1$ & 0,891 & Valid \\
\hline & & $\mathrm{X} 1.2$ & 0,835 & Valid \\
\hline & & $\mathrm{X} 1.3$ & 0,851 & Valid \\
\hline & & X1.4 & 0,880 & Valid \\
\hline \multirow{5}{*}{2} & \multirow{5}{*}{ Lingkungan Sosial $\left(\mathrm{X}_{2}\right)$} & $\mathrm{X} 1.1$ & 0,825 & Valid \\
\hline & & $\mathrm{X} 1.2$ & 0,809 & Valid \\
\hline & & $\mathrm{X} 1.3$ & 0,837 & Valid \\
\hline & & $\mathrm{X} 1.4$ & 0,832 & Valid \\
\hline & & $\mathrm{X} 1.5$ & 0,852 & Valid \\
\hline \multirow{3}{*}{3} & \multirow{3}{*}{ Niat Beli (Y) } & Y.1 & 0,851 & Valid \\
\hline & & Y.2 & 0,849 & Valid \\
\hline & & Y.3 & 0,886 & Valid \\
\hline
\end{tabular}

Tabel 1. Hasil Uji Validitas

Sumber: Data diolah, tahun 2017 
Hasil uji reliabilitas dengan nilai Cronbach's Alpha untuk masing-masing variabel > 0,6, ini berarti alat ukur tersebut akan memberikan hasil yang konsisten apabila alat ukur tesebut digunakan kembali untuk meneliti obyek yang samayang disajikan pada Tabel 2.

Tabel 2

\section{Hasil Uji Reliabilitas}

\begin{tabular}{clcc}
\hline No & \multicolumn{1}{c}{ Variabel } & $\begin{array}{c}\text { Cronbach's } \\
\text { Alpha }\end{array}$ & Keterangan \\
\hline 1 & Ekuitas Merek $\left(\mathrm{X}_{1}\right)$ & 0,886 & Reliabel \\
2 & Lingkungan Sosial $\left(\mathrm{X}_{2}\right)$ & 0,886 & Reliabel \\
3 & Niat Beli $(\mathrm{Y})$ & 0,827 & Reliabel \\
\hline
\end{tabular}

Sumber : Data diolah, tahun 2017

\section{Uji Asumsi Klasik}

1) Uji Normalitas

Uji normalitas bertujuan untuk menguji apakah suatu data berdistribusi normal atau tidak. Pada prinsipnya normalitas dapat dideteksi dengan melihat penyebaran data (titik) pada sumbu diagonal dari grafik atau dengan melihat histogram dari residualnya. Uji normalitas akan ditampilkan pada Tabel 3 hasil yang didapatkan dengan menggunakan uji Kolmogorov-Smirnov dengan signifikansi lebih besar dari 0,05 yaitu 0,917 maka dapat disimpulkan bahwa model regresi terdistribusi secara normal.

Tabel 3

Hasil Uji Kolmogorov-Smirnov

\begin{tabular}{llr}
\hline & & \multicolumn{2}{c}{$\begin{array}{c}\text { Unstandardized } \\
\text { Residual }\end{array}$} \\
\hline $\mathrm{N}$ & & 120 \\
Normal Parameters(a,b) & Mean & .0000000 \\
& Std, Deviation & .45322272 \\
Most Extreme Differences & Absolute & .051 \\
& Positive & .051 \\
\hline
\end{tabular}


E-Jurnal Manajemen Unud, Vol. 7, No. 1, 2018: 281-306

\begin{tabular}{llr}
\hline & Negative & -.046 \\
Kolmogorov-Smirnov Z & & .555 \\
Asymp. Sig. (2-tailed) & & .917 \\
\hline
\end{tabular}

Sumber : Data diolah, tahun 2017

2) Uji Multikolinearitas

Tabel 4

Hasil Uji Multikolinearitas

\begin{tabular}{clcc}
\hline & & \multirow{2}{*}{ Model } & \multicolumn{2}{c}{ Collinearity Statistic } \\
No & & Tolerance & VIF \\
\hline 1 & Ekuitas merk & 0.256 & 3.094 \\
2 & Lingkungan sosial & 0.256 & 3.094 \\
\hline
\end{tabular}

Sumber : Data diolah, tahun 2017

Tabel 4 di atas, dapat diketahui nilai VIF (Varian Inflatation Factor) tidak lebih dari 10 dan mempunyai angka tolerance tidak kurang dari 0,1, maka ini berarti dalam model regresi tidak terjadi multikolinearitas.

3) Uji Heteroskedastisitas

Tabel 5

Hasil Uji Heteroskedastisitas (Uji Glejser)

\begin{tabular}{clccccc}
\hline \multirow{2}{*}{ Model } & \multicolumn{7}{c}{$\begin{array}{c}\text { Unstandardized } \\
\text { Coefficients }\end{array}$} & $\begin{array}{c}\text { Standardized } \\
\text { Coefficients }\end{array}$ & $\mathrm{t}$ & Sig. \\
& & $\mathrm{B}$ & Std. Error & Beta & & \\
\hline 1 & (Constant) & .358 & .024 & & 14.826 & .000 \\
2 & Ekuitas merk & -.065 & .048 & -.234 & -1.350 & .180 \\
3 & Lingkungan sosial & .024 & .048 & .085 & -.491 & .624 \\
\hline Sumber : Data diolah, tahun 2017 & & & &
\end{tabular}

Berdasarkan tabel 5 diatas dapat dilihat bahwa hampir semua variabel memiliki nilai sig $>0,05$ ini berarti pada model regresi tidak terjadi gejala heteroskedasitisitas.

Analisis Regresi Linear Berganda 
Adapun hasil analisis regresi dengan program statitical pacage of social science (SPSS) versi 16.0 for Windows dapat dilihat pada Tabel 3 berikut.

Tabel 6

Rangkuman Hasil Analisis Regresi Linear Berganda

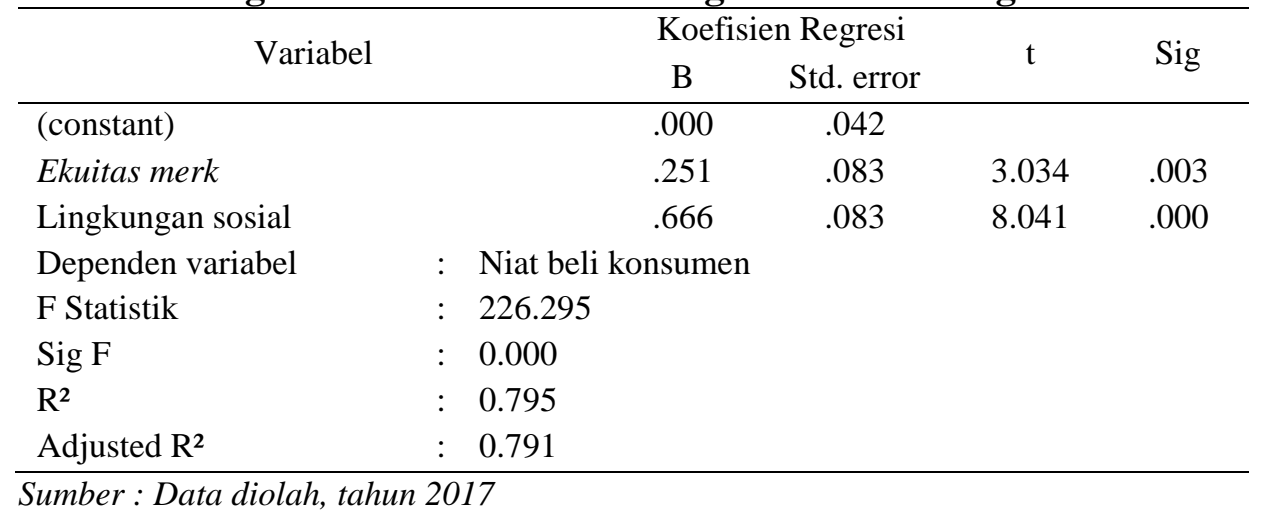

Berdasarkan Tabel 3 dapat ditulis persamaan regresi linear berganda sebagai berikut.

$$
Y=0,000+0,251 X_{1}+0,666 X_{2} \text {, yang dapat dijelaskan hal-hal sebagai }
$$
berikut.

Nilai koefisien $\beta_{1}=0,251$ berarti menunjukkan bila ekuitas merk $\left(\mathrm{X}_{1}\right)$ meningkat, maka nilai dari niat beli konsumen (Y) akan mengalami kenaikan dengan asumsi variabel bebas lainnya konstan.

Nilai koefisien $\beta_{2}=0,666$ berarti menunjukkan bila lingkungan sosial $\left(\mathrm{X}_{2}\right)$ meningkat, maka nilai dari niat beli konsumen (Y) akan mengalami kenaikan dengan asumsi variabel bebas lainnya konstan.

koefisien determinasi $\mathrm{R}^{2}$ memiliki nilai yang cukup tinggi yaitu 0,795 hal ini menandakan bahwa sebesar 79,5 persen variasi niat beli konsumen dapat 
dijelaskan oleh ekuitas merk dan lingkungan sosial sedangkan sisanya 20,5 persen dipengaruhi oleh faktor-faktor lain yang tidak diteliti.

\section{Uji F-test dan Uji Hipotesis (T-test)}

Nilai signifikansi $\mathrm{F}$ sebesar $0,000<0,05$ maka dapat disimpulkan ekuitas merk dan lingkungan sosial berpengaruh signifikan secara simultan terhadap niat beli konsumen. Hal ini berarti model dapat digunakan untuk analisa lebih lanjut atau dengan kata lain model dapat digunakan untuk mempresentasikan karena hasil goodness of fitnya baik.

Nilai signifikansi thitung ekuitas merk $\left(\mathrm{X}_{1}\right)$ sebesar 0,003 $<0,05$ maka $\mathrm{H}_{0}$ ditolak, ini berarti ekuitas merk berpengaruh positif terhadap niat beli konsumen pada produk Giordano di Kota Denpasar. Positif, erat, dan signifikan dalam arti kedua variabel antara ekuitas merk dengan niat beli konsumen saling berpengaruh besar/erat satu sama lain dengan didasarkan pada perhitungan olah data statistik yang signifikan. Hal ini menunjukkan bahwa semakin baik ekuitas merk pada suatu produk, maka ada kecenderungan niat beli konsumen pada produk Giordano semakin baik.

Nilai signifikansi $t_{\text {hitung }}$ lingkungan sosial $\left(\mathrm{X}_{2}\right)$ sebesar $0,000<0,05$ maka $\mathrm{H}_{0}$ ditolak, ini berarti lingkungan sosial berpengaruh positif terhadap niat beli konsumen pada produk Giordano di Kota Denpasar. Positif, erat, dan signifikan dalam arti kedua variabel antara lingkungan sosial dengan niat beli konsumen 
saling berpengaruh besar/erat satu sama lain dengan didasarkan pada perhitungan olah data statistik yang signifikan. Hal ini menunjukkan bahwa semakin baik lingkungan sosial masyarakat pada konsumen cenderung akan meningkatkan niat beli konsumen pada produk Giordano di Kota Denpasar.

\section{SIMPULAN DAN SARAN}

Berdasarkan pada pembahasan pada bab-bab sebelumnya, maka adapun halhal yang dapat disimpulkan yaitu, Ekuitas merek berpengaruh positif dan signifikan terhadap niat beli konsumen pada produk Giordano di Kota Denpasar. Lingkungan sosial berpengaruh positif dan signifikan terhadap niat beli konsumen pada produk Giordano di Kota Denpasar.

Berdasarkan simpulan, saran-saran yang dapat diberikan kepada pihak distributor pakaian Giordano di Kota Denpasar, sebagai distributor pakaian Giordano di Kota Denpasar harus memperhatikan ekuitas merk pada produk Giordano, maka dari itu produsen pakaian Giordano di Kota Denpasar harus dengan jelas menggambarkan mengenai produk merek Giordano dimata konsumen melalui modelnya, harga, dan bahan produknya sehingga konsumen sanggup dalam mengenali produk merek Giordano dan tertarik untuk melakukan pembelian. Sebagai distributor pakaian Giordano di Kota Denpasar harus memperhatikan situasi lingkungan sosial masyarakat di Kota Denpasar, melalui penjualannya harus mendorong karyawan agar mampu memberikan informasi mengenai produk Giordano lebih baik dan detail lagi kepada konsumen sehingga konsumen memiliki 
pendapat yang baik yang dapat dipromosikan kepada keluarganya, tetangganya dalam menambah referensi di dalam melalukan pembelian sehingga memiliki niat beli terhadap produk Giordano.

\section{REFERENSI}

Aaker A. David, 1997. "Manajemen Equitas Merek”. Jakarta:Spectrum Mitra Utama Andrie Ch. Salhuteru dan Harold Hursepuny, 2013. Analisa Ekuitas Merek terhadap Keputusan Pembelian Sepeda Motor Merek Yamaha di PT Hasjrat Abadi Cabang Ambon. Jurnal Manajemen Ekonomi dan Akuntansi. 2(1): h: 1-122

Ayu Putri Anggrihita Prabhawedasattya, I Gusti., dan Kerti Yasa, Ni. Nyoman., 2014. Pengaruh ekuitas merek terhadap preferensi merek dan niat beli konsumen pada produl Iphone di Kota Denpasar. Jurnal Manajemen Ekonomi. 16(1): h: 15251551

Eko Nurdin Kurnianto dan Budi Astuti, 2013. Analisis pengaruh komponen pembentuk ekuitas merek terhadap minat beli. Jurnal Manajemen Ekonomi Nasional. 4(1): h: 458-466

Ghozali, Imam, 2011, Aplikasi Analisis Multivariat/2, Badan Penerbit Undip, Semarang

Jamaliah Mohd. Yusof, Gurmit Kaur Bariam Singh, Rashidah Abdul Razak, 2013. Purchase Intention of Environment-Friendly Automobile. Journal Procedia - Social and Behavioral Sciences 8(5): h: 400 - 410

Joshi Pradeep, 2012. Effect of Environmental Concern and Social Norms on Environmental Friendly Behavioral Intentions. Business Intelligence Journal. 5(1): h: $169-175$

Johan wahyudi Amzah, 2010. Pengaruh gengsi, kepuasan dan komunikasi perusahaan terhadap woth of mouth dan niat beli kembali dengan variabel antara identifikasi merk (kasus pada produk Blacberry di Surabaya). Jurnal Ekonomi Erlangga. pp.1-128

Julina dan Desrir Miftah, 2014. Perbedaan perspektif konsumen berdasarkan gender terhadap niat beli produk asing. Jurnal Parallela. 1(1): h:1-88 
Kambiz Heidarzadeh Hanzaee and Mohammad Javad Taghipourian, 2012. The Effects of Brand Credibility and Prestige on Consumers Purchase Intention in Low and High Product Involvement. Journal Basic. Appl. Sci. Res., 2(2): h: 1281-1291

Kevin Goenawan, 2014. Pengaruh produk attributes, brand name, product price, dan social influence terhadap purchase intention Android Smartphone di Surabaya. Jurnal Ilmiah Ekonomi. 3(1): h: 1-17

Kuang-peng Hung, Annie Huiling Chen, Norman Peng, Chris Hackley, Rungpaka Amy Tiwsakul, Chun-lun Chou, 2011,"Antecedents of luxury brand purchase intention". Journal of Product \& Brand Management. 20(6): h: 457 - 467

Kuenzel, Sven \& Sue Vaux Halliday. 2008, "Investigating Antecedents and Consequences of Brand Identification". Journal of Product \& Brand Management. 293-304

Kotler, P. dan Keller, K.L.,2007, "Manajemen Pemasaran", Cet 2, Edisi 12, Jilid 1, Alih bahasa: Benyamin Molan. Penerbit PT INDEKS.

Kotler, Philip and G. Armstrong. 2012. Principles of Marketing. 14th ed. New Jersey: Prentice Hall.

Ling Lee, 2010. The Relationship between Global Brand and Country of Origin in Chinese Consumption Market. Journal Kwansei Gakuin University. 1(1): h: 88 - 112

Mangkunegara, A. A. Anwar Prabu. 2011. Manajemen Sumber Daya Manusia Perusahaan. Bandung: PT. Remaja Rosdakarya

Mowen, J. dan Minor, M. 2007. Perilaku Konsumen. Jakarta : Erlangga

Nick Hajli, M., 2013. A study of the impact of social media on consumers. International Journal of Market Research. 56(3): h: 387-404

Pavlou, P.A. 2003. "Consumer Acceptance of Electronic Commerce : Integrating Trus and Risk With The Technology Acceptance Model,"International Technology, 14(1): pp.39-52

Saadia Shabnam. 2013. Proposed Model for Predicting Environmental Purchase Behavior of Consumers. Journal European Academic Research. 1(4) h: 444-466

Santoso, Singgih. 2010. Buku Latihan SPSS Statistik Parametrik. Jakarta : Alex Media Komputindo.

Schiffman, Leon and Leslie Lazar Kanuk. 2007. Perilaku Konsumen Edisi Ketujuh. Prentice Hall, New Jersey 
Sreejesh, S., 2015. Consumers' Perceived Brand Aspiration and Its Impact on Intention to Pay Price Premium: Moderating Role of Brand Jealousy. Journal Theoretical Economics Letters. 5(1): h: 273-284

Sudomo, St. 2014. Pengaruh ekuitas merek terhadap keputusan pembelian pasta gigi Pepsodent di Kabupaten Bantul. Jurnal JBMA. 1(2): h: 33-48

Sugiyono, 2010. Metode Penelitian Bisnis. Cetakan Ke-15. Penerbit Alfabeta. Bandung.

Suprapti, Ni Wayan Sri. 2010. Prilaku Konsumen, Pemahaman Dasar dan Aplikasinya Dalam Strategi Pemasaran. Bali : Udayana University Press.

Suyana Utama, Made. 2009 "Buku ajar Aplikasi Analisis Kuantitatif. Denpasar :Fakultas Ekonomi Universitas Udayana

Swastha Basu, 2007. Manajemen Pemasaran, Analisis Perilaku Konsumen . Edisi Pertama . Cetakan Ketiga. Yogyakarta:BPFE

Tanya Ryan, 2014. Green Intentions: An Exploratory Study on Advertising and the Environmental Movement. Journal of research for Consumers. 27(7): h: 76-105

Tjiptono, Fandy, 2011. Strategi Pemasaran. Edisi Ketiga. Penerbit ANDI. Yogyakarta. Zikmun, Babin, 2011. Riset Pemasaran. Edisi Sepuluh

Umar Husein, 2007. Riset Pemasaran Dan Perilaku Konsumen. Jakarta : PT. Gramedia Pustaka Utama dan JBRC.

Yungki Hary Wibisono, 2010. Faktor-faktor yang mempengaruhi perilaku pembeilan dengan perilaku niat sebagai variabel intervening pada situs kaskus. Artikel ilmiah. pp.1-8

Zohreh Dehdashti Shahrokh and Arman Deilami Azodi, 2013. The Effect of Country of Origin Image on Brand Equity and Purchase Intention. Journal of Applied Environmental and Biological Sciences. 3(12): h: 52-61 
Mona Prabawa Putra, Putu., Pengaruh Ekuitas Merk dan... 